\title{
Ultrastructure of stromal calcification in mucoepidermoid carcinoma
}

\author{
Toshiyuki Kawakami, Chihito Nakamura, Hiromasa Hasegawa, \\ Shigeo Eda, Masataka Komatsu*, Kiyofumi Furusawa* \\ and Shoji Akahane** \\ Department of Oral Pathology, Department of Oral and \\ Maxillofacial Surgery II*, and Laboratory of Electron \\ Microscope**, Matsumoto Dental College, 1780 Gobara, \\ Hirooka, Shiojiri, Nagano 399-07, Japan
}

[Accepted for publication: February 1, 1986]

\begin{abstract}
Key words : mucoepidermoid carcinoma / stromal calcification / ultrastructure / abnormal epithelial secretion
\end{abstract}

\begin{abstract}
A case of mucoepidermoid carcinoma with calcified bodies in the stroma which appeared in a 24-year-old woman was studied ultrastructurally and electron-microanalytically. In this neoplasm, two types of abnormal epithelial secretions-flowing out type and basal secretion type--were observed. Calcified round bodies were noticed in the stromal tissues of this neoplasm. We discussed the relationship between the abnormal epithelial secretion into the stromal tissues and this calcification.
\end{abstract}

\section{Introduction}

There are many published papers of mucoepidermoid carcinoma, especially on their clinical and histopathological features, and also on the ultrastructural typing of their component cells (Sugár und Tóth 1967 ${ }^{1}$, Okuyama $1970^{2}$, Hübner \& Kleinsasser $1970^{3)}$, Komori et al. 1978 ${ }^{4}$, Chen $1979^{5)}$, Kawakami et al. $1984^{6)}$ ). We have studied the appearance of individual tumor cells of this neoplasm ultrastructurally and have also discussed the biological behavior of this neoplasm (Kawakami et al. 1984 ${ }^{7)}$ ). In salivary gland tumors, particularly pleomorphic adenomas, two types of abnormal epithelial secretion into the stromal tissue have been reported (Fukushima $\left.1968^{8}\right)$. Changes appeared in the stromal tissue of salivary gland tumors, and these have been studied histopathologically. However, to the best of our knowledge, no reports on abnormal epithelial secretion and stromal changes in mucoepidermoid carcinomas have ever been published. We were fortunate enough to experience a case of mucoepidermoid carcinoma with stromal calcification and studied its ultrastructural features (Akahane et al. 1984 ${ }^{9}$ ). Abnormal epithelial secretions of the tumor cells into the stromal tissues were observable in the same of mucoepidermoid carcinoma. The main purpose of this report is to discuss the relationship between this calcification and the abnormal epithelial secretion into the stromal tissues.

\section{Case Report}

A 24-year-old woman was admitted to the Matsumoto Dental College Hospital because of a painless, $10 \mathrm{~mm}$ in diameter, reddish mass had appeared in her right soft palate and had been present for a few years. Xray examination and routine clinical laboratory examinations were within normal limits. A biopsy was requested, and the histopathology findings were as follows (MDC 073-76) : The tumor mass was encapsulated with fibrous connective tissues. The neoplasm consisted mainly of three types of cells: mucous producing cells, epidermoid cells and intermediate cells. These proliferated tumor cells 


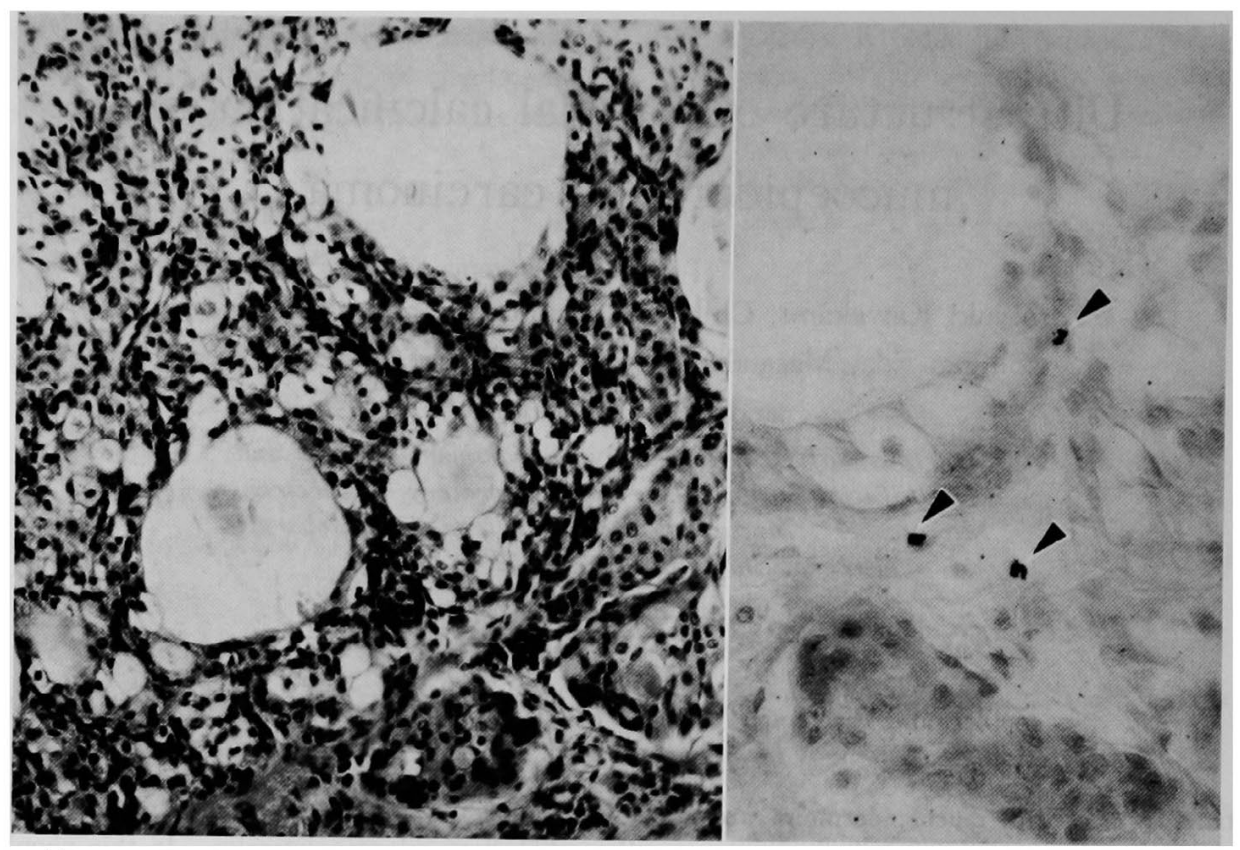

Fig. 1 Cystic cavities in the nest mainly composed of proliferating mucous producing cells and epidermoid cells (H.E, $\times 160$ ).

Fig. 2 Notice von Kossa's positive granules (arrow heads) in stromal connective tissue! $(\times 250)$ were comparatively solid. The intercellular stroma was composed of thin fibrous tissue. Cystic cavities were present in the tumor cell nests, and some of them were filled with amorphous material (Fig. 1) which substances stained strongly mucin positive. The tumor was diagnosed as a mucoepidermoid carcinoma (well differentiated type). The tumor was surgically removed. Postoperative progress was good (Furusawa et al. 1984 ${ }^{10}$ ).

\section{Examination Methods}

The mucoepidermoid carcinoma specimen was obtained from the patient during surgery, and for histology selected portions were fixed in $10 \%$ formalin solution, and embedded in parafin. After sectioning, the specimens were stained with the following reagents: hematoxylin-eosin (H-E), periodic acid Schiff (PAS), alcian blue, mucicarmine, van Gieson's, and von Kossa's stains.

For electron microscopy, the selected speci. mens were immediately fixed in ice-cold $2.5 \%$ glutaraldehyde buffered with $0.1 \mathrm{M}$ phosphate for 2 hours; it was postfixed in ice-cold $2 \%$ osmium tetraoxide buffered with vernal acetate for 2 hours. The tissue was then dehydrated through a graded ethanol series and embedded in Epon 812. After ultrathin sectioning with an ultramicrotome (LKB) equipped with a diamond knife (Diatome), the sections were either double-stained with uranyl acetate and lead citrate (U-Pb) or left unstained. These sections were examined ultrastructurally and electron-microanalytically. These examinations were carried out by a JEOL JEM 100-B electron microscope and a JEOL JEM 1200 EX analytic electron microscope, respectively.

\section{Results}

Ordinary Microscopic Findings :

The tumor cells proliferated as a solid pattern. The stroma was composed of thin fibrous tissue, which could only be observed in sections which had been stained with van Gieson's stain. In the stromal tissue, small granules were found which were von Kossa's positive (Fig. 2). The stroma also stained positively with PAS, alcian blue, and 


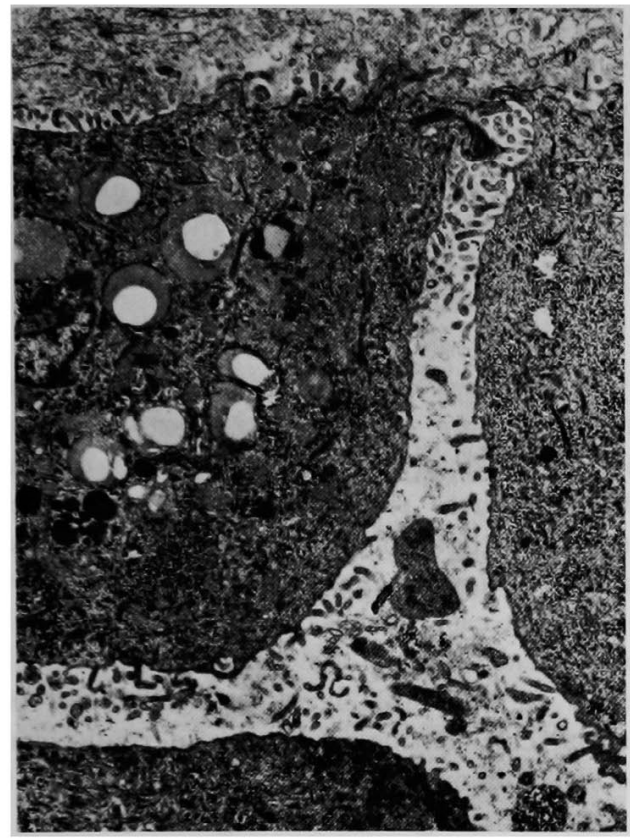

Fig. 3 Dissociated intercellular spaces of parenchymal cells $(\times 6,000)$

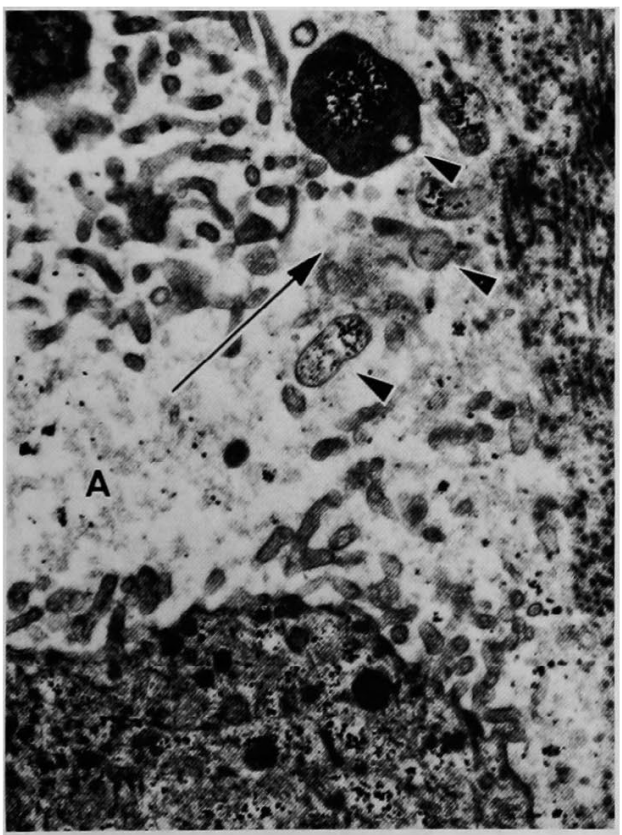

Fig. 4 Amorphous substances (A) and cell debris (arrow heads) flowing out into stroma (arrow) $(\times 13,000)$.

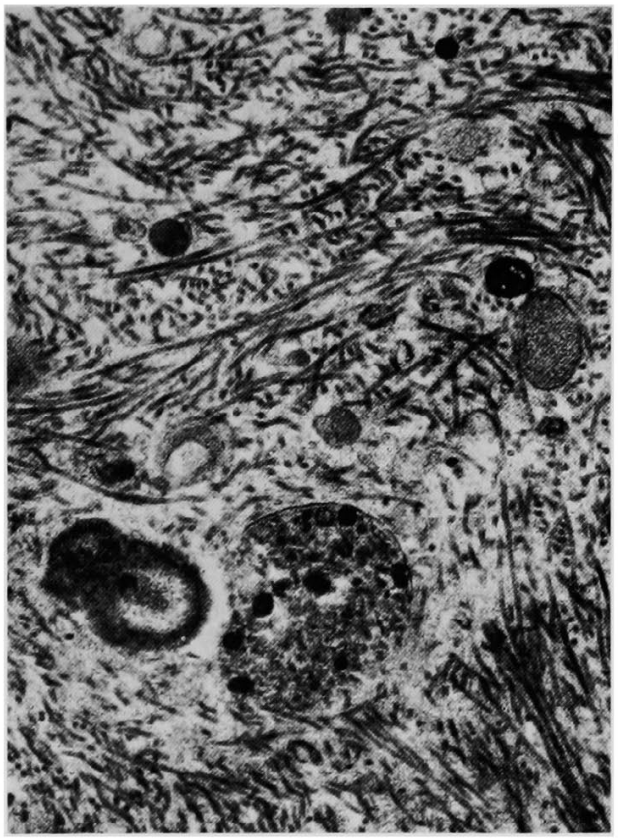

Fig. 5 Degenerated cell debris in stromal tissue $(\times 16,800)$.

mucicarmine stains.

Electron Microscopic and Electron Microanalytic Findings :

In the periphery of the tumor cell nests the intercellular spaces of parenchymal cells with some microvilli were sometimes continuous with the stroma through a rupture of the basement membrane and dissociation of contact between adjacent cells (Figs. 3, 4). Amorphous mucin-like substances and degenerated cell debris were found in these spaces. They appeared to have flowed out into the stromal tissues which contained abundant collagen fibers from the intercellular spaces (Fig. 5).

Generally on the periphery of the tumor cell nests, the basement membrane was present, but it was frequently missing in some parts. In the sites lacking a basement membrane, there was evidence of a direct secretion from the parenchymal cells into the collagen. ous tissues of the stroma, because elongated microvilli and serection substances were present (Fig. 6).

In the stromal tissue with abundant collagen fibers, no intracellular organelles are present but membranous structures and/or rou- 


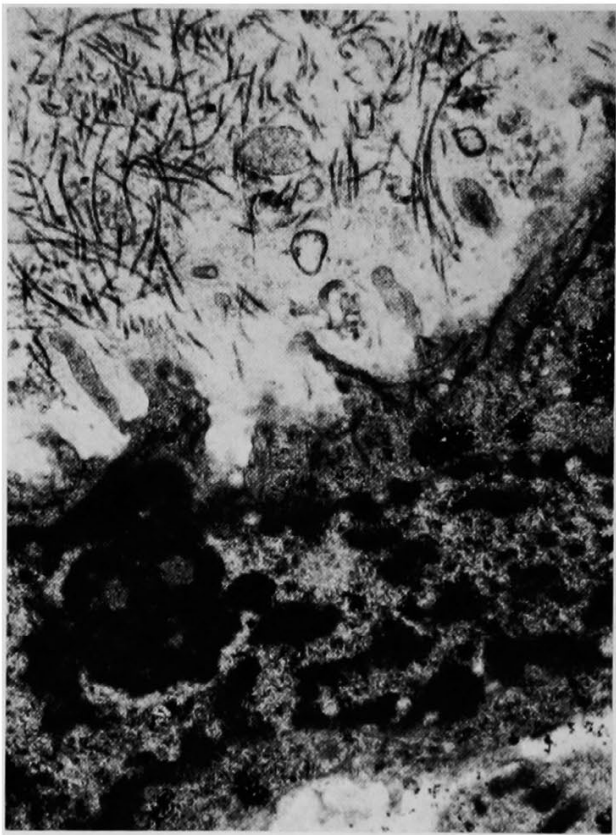

Fig. 6 Secretion directly from parenchymal cell into stroma containing collagen fibers $(\times 11,000)$.

nd structures were observed, some of these had an electron-dense periphery (Figs. 7,8 ). These electron-dense materials were com- posed mainly of calcium and phosphorus, according to electron-microanalysis (Fig. 9). But the amounts of calcium and phosphorus in these structures varied. The membranous structures resembled the cell debris or secreted substances, and some of them contained moderately electron-dense material (Fig. 10).

\section{Discussion}

Varied changes appear in the stromal tissue of salivary gland tumors, particularly in that of pleomorphic adenomas (Fukushima $\left.1968^{8}\right)$. These stromal changes have been studied histopathologically, ultrastructurally, and electron-microanalytically. Moreover, we reported a case of basal cell adenoma with stromal calcification (Nakamura et al. $1983^{111}$ ). As far as we know, however, no reports on stromal calcification in mucoepidermoid carcinoma (tumor) have been carried out until now.

Some investigators have reported that matrix vesicles or matrix vesicle-like structures appear in many kinds of pathological calcified sites (Kim 1976 ${ }^{12)}$, Kawakami et al. $1983^{13)}$, Kawakami $1984^{14)}$ ). In this study, membranous and/or round structures were found in the stromal tissues of this neoplasm.

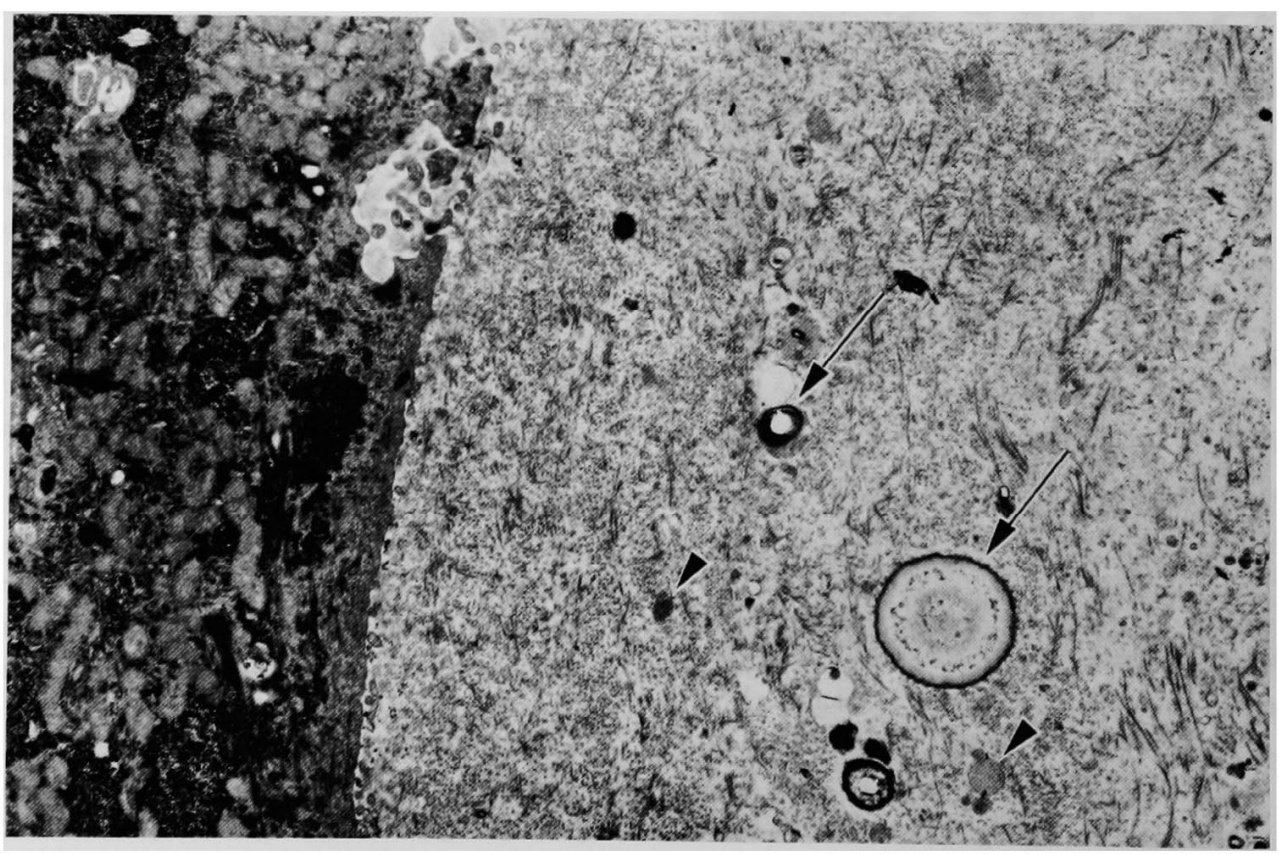

Fig. 7 Membranous (arrow heads) and round (arrows) structures in stroma $(\times 7,000)$. 


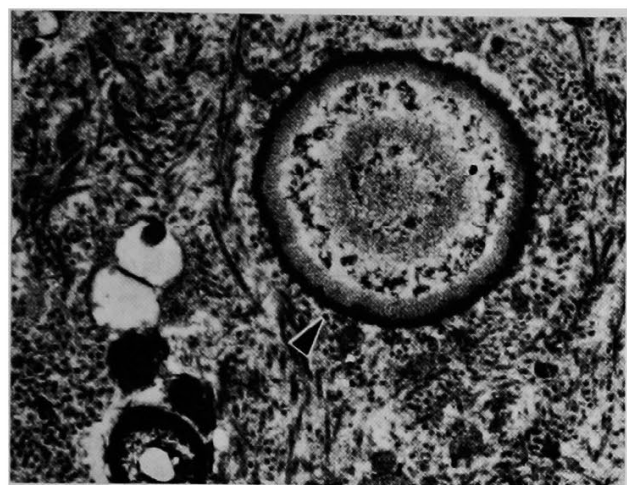

Fig. 8 Enlarged photograph of Fig. 7. Round structures with an electrondense periphery $(\times 15,000)$.

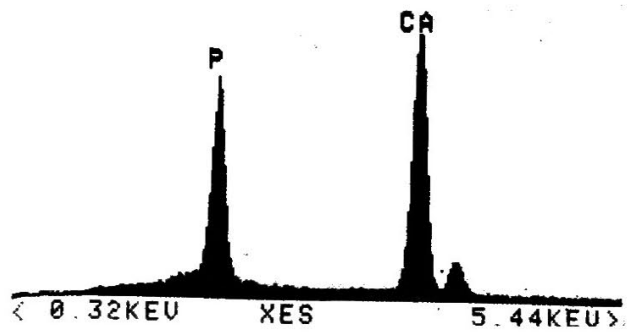

Fig. 9 EPMA of round structure (Fig. 8, arrow head) demonstrating a composition of $\mathrm{Ca}$ and $\mathrm{P}$.

While, these stromal calcified bodies were thought to be caused mainly by dystrophic changes, because of their appearance we believe that some of these structures have a matrix vesicle-like function. When these structures showing an electron-dense periphery were examined electron-microanalytically, these electron-dense materials were bound to consist of both calcium and phosphorus we therefore believe them to be calcified.

Komori et al. $(1978)^{15)}$ reported a case of mucoepidermoid tumor with calcification, but in their case the calcification was occurring in the cystic lumen and it was therefore, considered to be a kind of sialolith. In our case, there was the presence of an abnormal epithelial secretion into the stroma, since by ordinary microscopical observations the stromal tissues were stained positively with PAS,

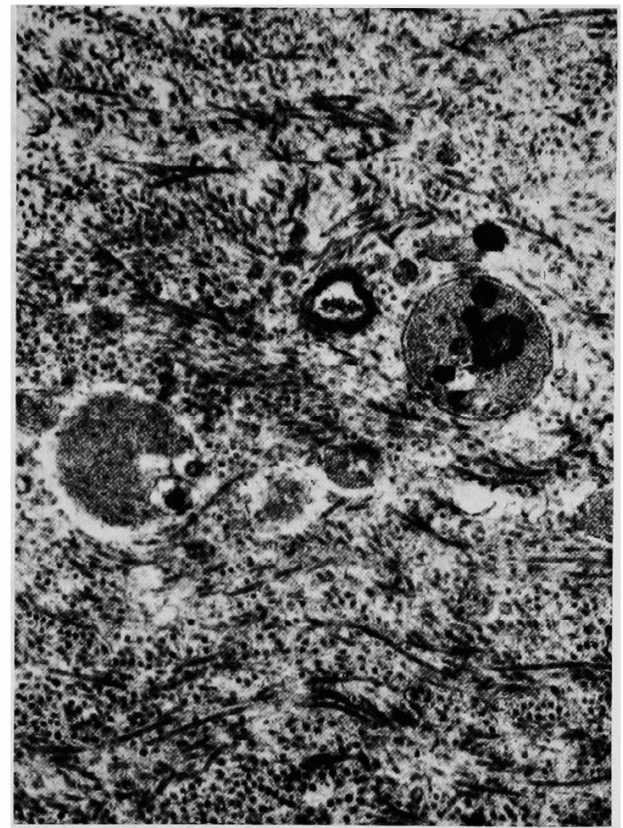

Fig. 10 Membranous and/or round structures containing moderately electron-dense materials $(\times 18,000)$.

alcian blue, and mucicarmine stains. Electron microscopically, two types of abnormal epithelial secretions were observed, which were considered to be the same as in pleomorphic adenomas and adenoid cystic carcinomas (Fukushima 1968 ${ }^{8 \prime}$ ). These abnormal epithelial secretions were termed "flowing out" type and "basal secretion" type, and we consider that they are due to holocrine and/or microapocrine types of secretion. The membranous and/or round structures in the stromal tissues were considered to have originated from these secretion substances or parenchymal cell debris due to abnormal basal secretion.

Therefore, we believe that these stromal calcifications are closely related to these types of abnormal epithelial secretion, i.e., the "flowing out" and "basal secretion" types.

\section{Acknowledgement}

This study was supported in part by a grant from the Ministry of Education, Culture and Science, Japan (No. 61570901).

抄録：24歳女性の口蓋に発現した分化型の粘表皮癌において，その間質に石灰化物の形成がみられたので， それの発現機序を解明することを主目的として，電子䫟微鏡的並びに分析電子顕微鏡的に検索した。胞巣辺 
縁部の腫崵細胞間は一部で離開し，その部に貯留した物質が基底膜の消失によって間質に流出するかの如き 構造が認められた。これとは別に間質に直接分泌を行なうように基底膜が欠如し, 微紴毛様構造が形成され ていたところもあった。膠原線維に富む間質には，小空胞状を呈する分泌顆粒ないし各種の細胞残渣様の膜 性構造物，および定性分析により P と Ca が高度に検出された球状石灰化物が多数存在していた。これら膜 性構造物の少なくとも一部は，上記の異常な上皮性分泌の結果生じたものであり，石灰沈着の母体となって いるものと考えられた。なお，これらのらちあるものは，基質小胞と構造的に類似しており，基質小胞的な 働きを持っているものと推察された。

\section{References}

1) Sugár, J. and Tóth, J.: Die Ultrastruktur des Mucoepidermoidalen Karzinomas, Zbl. Allg. Path. Bd. 110(S) : 329-334, 1967.

2) Okuyama, M.: Ultrastructure of pleomorphic adenoma and mucoepidermoid tumor appeared in palatine glands, J. Tokyo Dent. Coll. Soc. 70 : 593-645, 1970.

3) Hübner, G. and Kleinsasser, O. : Zur Feinstruktur und Genes des Mucoepidermoidtumors der Speicheldrusen, Virchows Arch. [Pathol. Anat.] 349 : 281-296, 1970.

4) Komori, A., Takeda, Y., Yamaguchi, A. and Ishikawa, G.: Ultrastructure of mucoepidermoid tumors of salivary glands, Jpn. J. Oral Biol. 20 : 771-781, 1978.

5) Chen, S. Y.: Ultrastructure of mucoepidermoid carcinoma in minor salivary glands, Oral Surg. $47:$ 247-255, 1979.

6) Kawakami, T., Nakamura, C., Kawasumi, M., Hasegawa, H., Eda, S., Komatsu, M., Furusawa, K. and Ideguchi, H. : Electron microscopic studies on mucoepiermoid carcinoma, I. Typing of component cells, Jpn. J. Oral Maxillofac. Surg. 30:605-611, 1984.

7) Kawakami, T., Nakamura, C., Hasegawa, H., Eda, S., Komatsu, M. and Furusawa, $\mathrm{K}$.: Electron microscopic studies on mucoepidermoid carcinoma, III. On the ultrastructural atypy, J. Matsumoto Dent Coll. Soc. $10: 121-129,1984$.

8) Fukushima, M.: An electron microscopic study of human salivary glands-pleomorphic adenoma and adenoid cystic carcinoma-, Bull. Tokyo Med. Dent. Univ. 15 : 387-408, 1968.

9) Akahane, S., Kawakami, T., Nakamura, C., Kawasumi, M., Hasegawa, H., Eda, S.,
Komatsu, M., Furusawa, K. and Ideguchi, H.: Electron microscopic studies on mucoepidermoid carcinoma, II. Calcified materials appeared in the stroma, J. Matsumoto Dent. Coll. Soc. $10: 29-41,1984$.

10) Furusawa, K., Komatsu, M., Shimada, H., Yamamoto, I., Nakamura, C., Kawakami, T., Machida, J. and Yamazaki, Y.: Two cases of mucoepiermoid carcinoma, J. Matsumoto, Dent. Coll. Soc. 10 : 136-144, 1984.

11) Nakamura, C., Kaneko, I., Hasegawa, H., Kawasumi, M., Kawakami, T., Eda, S., Akahane, S. and Yamazaki, T.: Studies on the pathological calcification, second report on the calcified materials appeared in basal cell adenoma, Jpn. J. Oral Biol. 25(S) : 289, 1983

12) Kim, K. M. : Calcification of matrix vesicles in human aortic valve and aortic media, Fed. Proc. 35 : 156-162, 1976.

13) Kawakami, T., Nakamura, C., Kawasumi, M., Hasegawa, H., Eda, S., Akahane, S., Yamazaki, T. and Takasu, N.: Studies on the pathological calcification, first report on calcinosis universalis, Jpn. J. Oral Biol. 25 (S) : 170, 1983.

14) Kawakami, T.: An experimental study on tissue reactions to a paste made of calcium hydroxide and iodoform an addition of silicone oil-with special reference to absorption of and calcification by the paste-, J. Tokyo Dent. Coll. Soc. 84 : 1563-1593, 1984.

15) Komori, A., Takagi, I., Okada, N. and Ishikawa, G.: Histopathological study of mucoepidermoid tumors of the salivary glands, J. Stomatol. Soc. Jpn. 45 : 263-279, 1978. 